\title{
Gastrointestinal parasitism in local and exotic breeds of chickens reared in Gwagwalada Guinea Savannah zone of Nigeria
}

\author{
OC Jegede ${ }^{1}$, IA Asadu ${ }^{1}$, M Opara $^{1}$, SS Obeta $^{1} \&$ DO Olayemi ${ }^{2}$ \\ 1. Department of Parasitology and Entomology, Faculty of Veterinary Medicine, University of Abuja, \\ Nigeria \\ 2. Veterinary Teaching Hospital, University of Abuja, Nigeria
}

*Correspondence: Tel.: +2348037023920, E-mail: ocjegede@yahoo.com

\begin{abstract}
The present study was carried out to establish the gastrointestinal parasites in local and exotic breeds of chickens reared in Gwagwalada, Guinea Savannah Zone of Nigeria. It was conducted between July and September, 2014. Two hundred and eighty (280) faecal samples from local and exotic breeds of chicken and 50 intact whole intestines were collected randomly from seven (7) major towns (Gwagwalada, Dobi, Gwako, Giri, Anagada, Tungan Maje and Zuba) in Gwagwalada Area council and examined for gastrointestinal parasites using flotation and sedimentation methods. Six (6) different gastrointestinal parasite eggs and oocytes were identified in $42.5 \%$ of the birds examined. Of these parasites, Ascaridia species was found to be the most prevalent (36.1\%) among the chickens. Other parasites encountered include; Eimeria oocytes (34.5\%), Heterakis species (12.6\%), Rallietina species 10.1\%; Capillaria species (4.2\%) and Syngamus species (2.5\%). There were mixed infection of $1.4 \%$ among the infected birds. Interestingly, none of the birds examined was infected with trematodes There was no significant difference $(p>0.05)$ in prevalence rate of infection between the local and exotic breeds of chickens. Although males had a higher prevalence of infection than the females in both breeds, there was no significant difference $(p>0.05)$ in the prevalence of infection among sexes. However, there was significant difference $(P<0.05)$ between the age groups, with highest infection occuring in growers (46.2\%). 20 (40\%) of the 50 intact whole intestines screened were positive for gastrointestinal parasites by gross examination of intestinal tract. Out of the 20 positive, 12 were nematodes, 3 cestodes and remaining 5 were mixed infections. Therefore, sustainable ways of controlling these parasites at a particular age and further studies on the prevalence of gastrointestinal parasites in chicken need to be elucidated for improved intensive egg and poultry meat productions
\end{abstract}

Keywords: Chickens, Exotic, Gastrointestinal, Local, Parasites, Prevalence

Received: 03-06- 2015

Accepted: 09-09-2015

\section{Introduction}

Poultry are domesticated birds kept by man for the purpose of obtaining meat, eggs and sometimes feathers. They include birds like chicken, duck, goose and turkey. Poultry are kept in backyards or commercial production systems in most areas of the world. It is one of the most important sources of protein and farm manure, for man (Frantovo, 2002).

In the last few years, with increase of poultry production, a lot of losses have been linked to disease causing agents such as viruses, bacteria and parasites (Sayyed et al., 2000). Although parasitic diseases are among the major factors that decrease productivity of chickens, they are often neglected as they are most times subclinical. Parasitism is one of the major problems which inflict heavy economic losses to poultry production in the form of retarded growth, reduced weight gain, decrease egg production, diarrhea, intestinal obstruction and poor feathers. Stress from parasites could affect the blood picture and cause anorexia (Dube et al., 2010). However, there is a reduction in parasitic infection in commercial poultry production mostly due to improved housing, hygiene and management practices. The domestic chicken feed on a wide range of food substances ranging from grains, fruits to insects which may harbor infective stages of parasites 
thereby predisposing them to parasitic infection, particularly gastrointestinal parasites (Oniye et al., 2000; Frantovo, 2002).

The prevalence and intensity of helminths infections may be influenced by several factors, including those that pertain to the host such as age, sex and breed. Furthermore, climatic conditions may alter the population dynamics of the parasites resulting in dramatic changes in the prevalence and intensity of helminths infection (Magwisha et al., 2002). Many insects that act as vectors for helminths are also favored by high temperature and to some extent humidity. These factors may explain the wide range and distribution of nematode and cestodes species in poultry, especially during the tropical rainy season (Dube et al., 2010). In the past, few studies have analyzed the incidence of helminthe parasites in the free-range local or backyard and commercial chickens in different parts of the country (Eshetu et al., 2001; Ashenafi \& Eshetu, 2004) with less information on the parasites especially around the Federal Capital Territory, Abuja. This study, is therefore, aimed at investigating the gastrointestinal parasites of local free range and exotic breeds of chickens reared in 7 major towns in Gwagwalada Area Council, Guinea Savannah zone of Nigeria.

\section{Materials and methods}

Study area

This study was conducted in the Gwagwalada Area Council which is one of the six Area Councils of the Federal Capital Territory, Abuja, Nigeria. It is located geographically in the central part of Nigeria, between latitudes $8^{0}$ and $9^{\circ} \mathrm{N}$ and longitudes $6^{\circ}$ and $7^{\circ} \mathrm{E}$. It has a guinea savannah type of vegetation, with rainy season stretching from April to October and dry season, November to March. The temperature ranges from $30-37^{\circ} \mathrm{C}$ yearly with the highest temperature of the area experienced in the month of March. Other towns included in this area council are Dobi, Tunga-Maje, Zuba, Igwa, Giri, Anagada, Ibwa, Sheriagu, Shaga, etc.

\section{Study methods}

A total of 280 freshly voided faecal samples, 140 each of local and exotic breeds of poultry and 50 intact whole intestines of both local and exotic breeds of chickens were collected randomly from 7 towns in Gwagwalada Area Council, between July and September 2014. From each town, a total of 40 faecal samples were collected. Chickens of different age groups and sexes kept in deep litter system were included in the study. The samples were collected with a spatula, which was washed and cleaned after each collection to avoid contamination. Each faecal sample was placed in a sample bottle and labeled properly indicating the towns, dates, breed and sex of the chicken.
Direct microscopic examination, centrifugation floatation technique and sedimentation technique as described by Urquhart et al. (1987) were used to investigate faecal sample. Identification of the eggs or oocyst made on the basis of morphorlogy and size of eggs.

Faecal samples obtained were examined using saturated concentrated sugar solution floatation and sedimentation techniques and eggs or oocysts identified using the light microscope at x100 objective.

50 intact whole intestines 25 each of local and exotic poultry breeds were collected at slaughter in Gwagwalada main market. The intestines were dissected longitudinally and screened for the presence of helminth parasites. The adult parasites removed from the intestines wre preserved in $10 \%$ formalin for identification.

Data collected on prevalence and numbers of gastrointestinal parasites in faecal samples of each breed were statistically analyzed using simple statistical method such as percentage, student ttest and Chi square $\left(\chi^{2}\right)$. The test statistics was applied at 0.05 level of significance, to test whether or not there were significant differences.

\section{Results}

The result revealed that nematodes had the highest prevalence rate of infection in both the local and exotic breeds, with Ascaridia species having the highest prevalence rate followed by Heterakis species. The percentage prevalence recorded was $15.4 \%$ and $5.4 \%$ respectively. Capillaria species and Syngamus species had prevalence rates of $1.8 \%$ and $1.1 \%$ respectively. The protozoan species recorded was Eimeria oocyst with a prevalence of $14.6 \%$, while the cestode species recorded was Rallietina species with a prevalence of $4.3 \%$ (Table 1 ). The overall prevalence according to breed is as shown in table 2. The prevalence of infection in local breed was $44.3 \%$ while that for the exotic breed was $20.4 \%$ In table 3, parasites preference in relation to sex and age were also observed. Out of the 79 males examined, $46.8 \%$ were infected by the gastrointestinal parasites while out of the 201 female birds examined, $40.8 \%$ were positive for gastrointestinal parasites, although, this was not statistically significant $(P>0.05)$. Chickens within the age group of $7-15 w k s$ (growers) were more significantly $(P<0.05)$ infected than the chicks, but not $(P>0.05)$ more than the adults. (Table 4). In Exotic breeds, males had a significantly $(P<0.05)$ higher occurrence infection rate of $72.7 \%$ than $44.9 \%$ of females examined (Table 5 ). Again, the exotic chicks recorded significantly $(P<0.05)$ lower rate of infection (28.6\%) when compared with the growers (Table 6). In local breeds, female birds had a higher rate of infection (48.2\%) as against the $36.8 \%$ of the male, although, this was not 
significant ( $P>0.05)$ (Table 7). Also, Adults recorded $48.3 \%$ of infection as against the other age group (Table 8).

Among the 50 whole intestines screened for the presence of gastrointestinal parasites, 20 were found positive for gastrointestinal parasites by gross examination of the gastroitetsinal tract with Ascaridia species accounting for 12, Rallietina species 3 and 5 were mixed infections of both (Plates I, II \& III)

In the local breed, 16 out of the 25 intact whole intestines screened were positive for gastrointestinal parasites giving a prevalence of $64 \%$. While in the exotic birds $4(16 \%)$ out of the 25 intact whole intestines screened were positive for gastrointestinal parasites.

Table 1: Overall prevalence of gastrointestinal parasites of chicken $(n=280)$

\begin{tabular}{lcc}
\hline \multicolumn{1}{c}{ Parasites } & No. Infected(n=280) & \% Prevalence \\
\hline Ascaridia species & 43 & 15.4 \\
Eimeria oocyst & 41 & 14.6 \\
Heterakis species & 15 & 5.4 \\
Rallietina species & 12 & 4.3 \\
Capillaria species & 5 & 1.8 \\
Syngamus species & 3 & 1.1 \\
\hline \multicolumn{1}{c}{ Total } & $\mathbf{1 1 9}$ & $\mathbf{4 2 . 5}$ \\
\hline
\end{tabular}

Table 2: Prevalence of gastrointestinal parasites of chickens according to Breed $(n=280)$

\begin{tabular}{llccc}
\hline & Variables & No. of birds examined & No. (\%) infected & No. (\%) not infected \\
\hline \multirow{2}{*}{ Breed } & Local & 140 & $62(44.3)$ & $78(55.7)$ \\
& Exotic & 140 & $57(40.7)$ & $83(59.3)$ \\
\hline Total & 280 & $119(42.5)$ & $161(57.5)$ \\
\hline$\chi 2=0.3654$ & $P=0.5455$ & & &
\end{tabular}

Table 3: Prevalence of gastrointestinal parasites of chickens according to sex

\begin{tabular}{lllll}
\hline & Variables & No. of birds examined & No. (\%) infected & No. (\%) not infected \\
\hline Sex & Male & 79 & $37(46.8)$ & $42(53.2)$ \\
& Female & 201 & $82(40.8)$ & $49(59.2)$ \\
\hline Total & 280 & $119(42.5)$ & $161(57.5)$ \\
\hline X2 $=0.8464$ & $\mathrm{P}=0.3576$ & &
\end{tabular}

Table 4: Prevalence of gastrointestinal parasites of chickens according to age

\begin{tabular}{|c|c|c|c|c|}
\hline & Variables & No. of birds examined & No. (\%) infected & No. (\%) not infected \\
\hline \multirow[t]{3}{*}{ Age } & 0-6wks (chicks) & 70 & $21(30)$ & $49(70)$ \\
\hline & 7-15wks (Grower) & 93 & $47(50.5)$ & $46(49.5)$ \\
\hline & $>16 w k s$ (Adults) & 117 & $51(43.6)$ & $66(56.4)$ \\
\hline Total & & 280 & $119(42.5)$ & $161(57.5)$ \\
\hline
\end{tabular}

$\chi 2=6.991 \quad P=0.03033$

Table 5: Prevalence of gastrointestinal parasites in exotic chickens according to sex $(n=140)$

\begin{tabular}{|c|c|c|c|c|}
\hline & Variables & No. of birds examined & No. (\%) infected & No. (\%) not infected \\
\hline Sex & Male & 22 & $16(72.7)$ & $6(27.3)$ \\
\hline & Female & 118 & $53(44.9)$ & $65(55.1)$ \\
\hline Total & & 140 & $69(49.3)$ & $71(50.7)$ \\
\hline
\end{tabular}

Table 6: Prevalence of gastrointestinal parasites in exotic chickens according to age $(n=140)$

\begin{tabular}{lllll}
\hline & Variables & No. of birds Examined & No. (\%)infected & No. (\%)not infected \\
\hline Age & 0-6wks (chicks) & 35 & $10(28.6)$ & $25(71.4)$ \\
& 7-15wks (Grower) & 48 & $26(54.2)$ & $22(45.8)$ \\
& $>16 w k s$ (Adults) & 57 & $21(36.8)$ & $36(63.2)$ \\
\hline \multicolumn{2}{l}{ Total } & 140 & $57(40.7)$ & $83(59.3)$ \\
\hline X2 $=6.091 \quad P=0.04758$ & &
\end{tabular}


Table 7: Prevalence of gastrointestinal parasites in Local chickens according to sex $(n=140)$

\begin{tabular}{|c|c|c|c|c|}
\hline & Variables & $\begin{array}{l}\text { No. of birds } \\
\text { examined }\end{array}$ & $\begin{array}{ll}\text { No. } & \text { (\%) } \\
\text { infected }\end{array}$ & $\begin{array}{l}\text { No. (\%) } \\
\text { not infected }\end{array}$ \\
\hline \multirow[t]{3}{*}{ Sex } & Male & 56 & $21(37.5)$ & $35(62.5)$ \\
\hline & Female & 84 & $41(48.8)$ & $43(51.2)$ \\
\hline & Total & 140 & $62(44.3)$ & $78(55.7)$ \\
\hline$\chi 2=1.8$ & $P=0.1799$ & & & \\
\hline
\end{tabular}

Table 8: Prevalence of gastrointestinal parasites in Local chickens according to age $(n=140)$

\begin{tabular}{lllll}
\hline & Variables & $\begin{array}{l}\text { No. of birds } \\
\text { Examined }\end{array}$ & $\begin{array}{l}\text { No. } \\
(\%) \text { infected }\end{array}$ & $\begin{array}{l}\text { No. } \\
\text { infected }\end{array}$ \\
\hline Age & 0-6wks (chicks) & 35 & $10(28.6)$ & $25(71.4)$ \\
& 7-15wks (Grower) & 45 & $23(51.1)$ & $22(48.9)$ \\
& $>16 w k s$ (Adults) & 60 & $29(48.3)$ & $31(51.7)$ \\
\hline Total & & 140 & $62(44.3)$ & $78(55.7)$ \\
\hline$\chi 2=4.751$ & $\mathrm{P}=0.09297$ & & &
\end{tabular}

\section{Discussion}

The overall prevalence of infection with gastrointestinal parasites recorded in this study was $42.5 \%$. This finding is in agreement with the previous report of $35.5 \%$ by Nnadi \& George, (2010) from Nsukka and $37.6 \%$ by Agbolade et al. (2014) from ljebu North, South Western Nigeria and by Shiferaw et al. (2012) from Ethiopia.

The prevalence of $42.5 \%$ recorded here was greatly lower than $92.6 \%$ reported by Mikail \& Adamu (2008) in Sokoto Metropolis; $96.3 \%$ by Fakae \& Paul-Abiade (2003), in Nsukka; $81.5 \%$ by Junaidu et al. (2014) in Giwa, Kaduna State; $63.6 \%$ by Ogbaje et al. (2012) in Makurdi and $59.64 \%$ by Yehualashet (2011) in Ethiopia This discrepancy could be related to the differences in the management systems, control practices in the farms and seasonal differences. It has been reported that these factors exacerbates the infection of domestic birds in the tropics (Opara et al., 2014). Ascaridia species had the highest prevalence rate in both local and exotic breeds. Similar reports have been documented from other parts of Nigeria; Zaria in Kaduna State (Luka \& Adams, 2007), Jos in Plateau State (Pam et al., 2006) and Nsukka in Enugu State (Nnadi \& George, 2010). In other climes, especially Africa, several studies have strongly suggested that Ascaridia galli is the commonest and most important helminths of poultry (Eshetu et al., 2001; Kaingu et al., 2010). Syngamus species that was absent in exotic breed had low prevalence rate in local breed (2.5\%). This is in agreement with Pam et al. (2006), Luka \& Ndams, (2007) who reported in their work that this parasite has low prevalence rate of infection compared to the other helminth parasites.

Although, the overall prevalence of infection in local breeds (44.3\%) was higher than the exotic breeds (40.7\%), there was no significant difference $(P>0.05)$ in the rate of infection between breeds. This study showed that there was significant difference $(p<0.05)$ among the age groups, with highest infection rate occurring in grower birds (50.6\%) using the Chi Square test, thus indicating that age played a role in the infection of the birds with gastrointestinal worms. This could be attributed to the existing maternal immunity in the chicks and the longer exposure of the older birds to both helminth ova and coccidian oocyst from the environment.

As was observed in previous studies by Uhuo et al. (2013), Magwisha et al. (2002), Ashenafi \& Eshetu (2004), and Hirut (2009), the result of the present study showed that there was no sexual dimorphism with regards to helminth infection of the birds examined.

The gross parasites found were in accordance with Puttalakshmamma et al. (2008) who found positive infections in local fowls in intestinal examination in and around Banglore.

In conclusion, this study revealed a higher but not so significant prevalence of gastrointestinal parasitism in the exotic breed of chicken and that sex did not influence the rate at which the birds were infected.

Ascaridia species was the most prevalent gastrointestinal parasite affecting the chickens reared in Gwagwalada Area Council of Abuja.

Poor deworming regime, health care, and improper sanitation are among the major factors responsible for the high prevalence of gastrointestinal parasitism in the farm.

Therefore, sustainable ways of controlling these parasites through proper and timely deworming of the local and exotic chickens would help to improve egg and poultry meat production. 
It is also therefore, recommended that, appropriate deworming and treatment of infected birds be carried out regularly, particularly at the grower stage by a Veterinarian. In addition, proper and adequate nutrition would also minimize the incidence rate of helminthosis of domestic birds in the Area Council.

\section{References}

Agbolade OM, Arosoye AS, Akajiugo EC, Akinyemi AA, Owolowo AM, Ariba O \& Jonathan KA (2014). Gastrointestinal parasite of domestic fowl from ijebu North, South western Nigeria. Basic Research Journal of Agricultural Sciences, 3(7): 60-64.

Ashenafi H \& Eshetu $Y$ (2004). Study on sastrointestinal helminths of local chickens in Central Ethiopia. Journal of Veterinary Medicine. 155(10): 504-507.

Dube S, Zind IP, Mbanga J \& Dude C (2010). A Study of scavenging poultry gastrointestinal and ecto-parasites in rural areas of Matebeleland Province, Zimbabwe. International Journal of Poultry Sciences, 9 (9): 911-915.

Eshetu Y, Mulualem E, Ibrahim H, Berhanu A \& Aberra K (2001). Study of gastrointertinal helminthes of scavenging chickens in four rural districts of Amhara region, Ethiopia. Revision Science Techniques Office International Epizootic, 20(3): 791-796.

Fakae BB \& Paul-Abiade CU (2003). Rainy season period prevalence of Helmiths in the Domestic (Gallus gallus) in Nsukka, Eastern Nigeria. Nigeria Veterinary Journal, 24 (1): 21-27.

Frantovo D (2002). Some parasitic nematodes (Nematoda) of birds (ayes) in The Czech Republic. Acta Societatis Zoologicae Bohemicae 66 (1):13-28.

Hirut A (2009). Study on the prevalence of endoparasites in chickens in Haramaya University Poultry Farm. DVM thesis, Haramaya University, College of Veterinary Medicine, Haramaya, Ethiopia. Pp 1-37.

Junaidu HC, Luka SA \& Mijinyawa A (2014). Prevalence of gastrointestinal helminth parasites of the domestic fowl (Gallus gallus domesticus) slaughtered in Giwa market, Giwa local Government Area, Kaduna state, Nigeria. Journal of National Science Research, 4(19): 54-58.

Kaingu F, Kibor A, Shivairo R, Kutima H, Okeno T, Wayhenya R \& Kahi AK (2010). Prevalence of gastrointestinal helminthes and

\section{Acknowledgement}

We gratefully acknowledge the farmers and slaughterhouse workers for granting access to their animals and assisting with sample collection.

coccidian in indigenous chicken from different agro-climatic zones in Kenya. African Journal Agricultural Research. 5(6): 458-462.

Luka SA \& Ndams IS (2007). Gastroinstestinal parasites of domestic chickens, Gallus gallus domesticus (Linnaeaus 1758) in Samaru, Zaria, Nigeria. Science World Journal, 2(1): 27-29.

Magwisha $H$, Kassuku A, Kyvsgaard N \& Permin A (2002). A comparison of the prevalence burden of helminth infections in growers and adult free range chickens. Tropical Animal Health Production, 34(3): 205-214.

Mikail HG \& Adamu YA (2008). A survey of the gastrointestinal helmiths of chickens in Sokoto metropolis, Nigeria. Nigeria Veterinary Journal, 29(1): 72-75.

Nnadi PA \& George SO (2010). A Cross-sectional survey on parasites of chickens in selected villages in the sub humid zones of South-Eastern Nigeria. Journal of Parasitology Research, ID 141824.

Ogbaje Cl Agbo EO \& Ajanusi OJ (2012). Prevalence of Ascaridia galli, Heterakis gallinarum and tbpeworm infection in Birds slaughtered in Makurdi township. International Journal of Poultry Science, 11(2):103-107.

Oniye SJ, Audu PA, Adebote DA, Kwaghe BB, Ajanusi OJ \& Nfor MB (2000). Survey of helminth parasites of laughing Dove, Streptopelia segalensis in Zaria - Nigeria. African Journal of Natural Sciences, 4: 6566.

Opara MN, Osowa DK \& Maxwell JA (2014). Blood and gastrointestinal parasites of chickens and turkeys reared in the tropical rain forest zone of South Eastern Nigeria. Open Journal of Veterinary Medicine, 4(12): 308-313.

Pam VA, Daniel LN, Brengshak S, Wai MS, Omalu CJ \& Ashi RD (2006).The survey of intestinal parasites of local and exotic chickens slaughtered at Yankari market, Jos, Plateau State. Journal of Medical and Pharmaceutical Science, 2(3):27-30. 
Puttalakshmamma GC, Ananda KJ, Prathiush PR, Mamatha GS \& Suguna R (2008). Prevalence of gastrointestinal parasites of Poultry in and around Banglore. Veterinary World, 1(7): 201-202.

Sayyed R, Phulan M, Bhatti W, Pardehi M \& Ali S (2000). Incidence of nematode parasites in commercial layers in swat. Pakistan Veterinary Journal, 20(2): 107-108.

Shiferaw TZ, Gemeda AE \& HZ. (2012). Helminothosis of chickens in selected small scale commercial poultry farms in and around Haramaya Woreda, Southeasthern Ethiopia. Journal of Veterinary Advances, 2(9): 462-468.

Uhuo AC, Okafor FC, Odikamnoro OO, Onwe CS, Abarike MC \& Elom JN (2013). Common gastrointestinal parasites of local chicken (Gallus domesticus) slaughtered in some selected eatery centres in Abakaliki, Ebonyi state, International Journal of Development and Sustainability, 2(2): 1416-1422.

Urquhart GM, Armour J, Duncon JL, Dunn AM \& Jennings FW (1987). Veterinary Parasitology. Longman Group UK Ltd., England. Pp. 19, 276-277.

Yehualashet B (2011). A study on the prevalence of the helminth parasites in free range (backyard) chicken in selected small holder farms in and around Haramaya DVM thesis, college of Veterinary Medicine, Haramaya University, Ethiopia. Pp 1-48. 